\title{
PENGARUH KOMPOS JERAMI PADI TERHADAP PERTUMBUHAN DAN HASIL TANAMAN KAILAN (Brassica alboglabra, L.) PADA TANAH PODSOLIK MERAH KUNING
}

\author{
Nining Sri Sukasih \\ Fakultas Pertanian Universitas Kapuas Sintang \\ Email : niningskasih@gmail.com
}

\begin{abstract}
Abstrak: Penelitian ini bertujuan untuk mengetahui pengaruh kompos jerami padi terhadap pertumbuhan dan hasil tanaman kailan pada tanah podsolik merah kuning serta untuk mengetahui dosis kompos jerami padi yang berpengaruh terhadap pertumbuhan dan hasil tertinggi. Ruang lingkup penelitian ini terdiri dari variabel bebas dan variabel terikat. variabel bebas yaitu kompos jerami padi sedangkan variabel terikat yaitu tinggi tanaman, diameter batang per tanaman, dan berat segar tanaman. Rancangan percobaan digunakan adalah Rancangan Acak Kelompok dengan faktor perlakuan kompos jerami padi yang terdiri dari : ( $\left.\mathrm{j}_{0}\right)$ tidak diberi kompos jerami padi, $\left(\mathrm{j}_{1}\right)$ 0,5 kg kompos jerami padi per $\mathrm{m}^{2},\left(\mathrm{j}_{2}\right) 1 \mathrm{~kg}$ kompos jerami padi per $\mathrm{m}^{2},\left(\mathrm{j}_{3}\right)$ 1,5 $\mathrm{kg}$ kompos jerami padi per $\mathrm{m}^{2}$, (j4) $2 \mathrm{~kg}$ kompos jerami padi per $\left.\mathrm{m}^{2}, \mathrm{j}_{5}\right) 2,5 \mathrm{~kg}$ kompos jerami padi per $\mathrm{m}^{2},\left(\mathrm{j}_{6}\right) 3 \mathrm{~kg}$ kompos jerami padi per $\mathrm{m}^{2}$
\end{abstract}

Kata Kunci: Tanah PMK, Kompos Jerami Padi, Kailan, Pertumbuhan, Hasil

\section{PENDAHULUAN}

$$
\text { Produksi tanaman kailan di }
$$

Kabupaten Sekadau masih tergolong rendah, dari data BPS Kabupaten

Sekadau Tahun 2014 belum ada catatan mengenai produksi kailan. Tanaman kailan cukup diminati oleh masyarakat dari hasil pengamatan di lapangan diketahui bahwa tanaman kailan yang beredar di pasar harus diambil dari luar Sekadau dan sebagian besar dari Pontianak. Sayuran kailan ini banyak diminati oleh para pengusaha rumah makan, khususnya rumah makan chinese food. Berdasarkan hasil wawancara dengan beberapa pengusaha rumah makan yang ada di kota Sekadau harga kailan per kilogramnya rata-rata $\mathrm{Rp}$. 60.000 , tingginya harga jual sayuran ini memberikan peluang yang menjanjikan untuk mengembangkannya di Sekadau. Jika dilihat dari perkembangannya tanaman ini cukup baik tumbuh di Sekadau dan ini terlihat dari beberapa petani yang mengusahakan tanaman ini.

Tanaman kailan dapat tumbuh disemua jenis tanah, namun untuk mendapatkan pertumbuhan yang memiliki nilai ekonomi yang tinggi maka dalam budidaya tanaman kailan harus memperhatikan ketersediaan unsur hara yang cukup. Unsur hara yang cukup 
hanya diperoleh pada tanah yang subur dan banyak bahan organik, kondisi tanah seperti ini tidak diperoleh pada tanah PMK karena tanah ini banyak mengandung $\mathrm{Al}$ dan $\mathrm{Fe}$ dan bahan organiknya rendah. Agar diperoleh pertumbuhan dan hasil kailan yang memiliki nilai ekonomi tinggi tanaman perlu diberi pupuk. Pupuk yang diberikan pada tanaman juga harus memperhatikan kondisi tanah, karena pemberian pupuk yang tepat akan mempengaruhi aktifitas mikroba tanah sehingga unsur hara dapat tersedia bagi tanaman.

Pupuk organik yang dapat digunakan atau diaplikasikan pada tanah PMK salah satunya adalah pupuk kompos jerami padi, pupuk ini mengandung unsur hara yang lengkap yaitu unsur hara mikro dan unsur hara makro, selain itu kompos jerami padi dapat memperbaiki sifat fisik dan kimia tanah. Pemberian kompos jerami padi dalam jumlah yang banyak juga tidak merugikan lingkungan, hal ini juga didukung oleh ketersediaannya di mana untuk Kecamatan Belitang Hilir khususnya di desa Merbang luas sawah sampai tahun 2015 menurut data Badan Penyuluh Pertanian Kecamatan Belitang dihasilkan dalam tiap hektar rata-rata 12 ton setiap musim panen.

\section{METODOLOGI PENELITIAN}

Rancangan percobaan digunakan adalah Rancangan Acak Kelompok dengan faktor perlakuan kompos jerami padi yang terdiri dari : $\left(\mathrm{j}_{0}\right)$ tidak diberi kompos jerami padi, ( $\mathrm{j}_{1}$ ) 0,5 kg kompos jerami padi per $\mathrm{m}^{2},\left(\mathrm{j}_{2}\right) 1 \mathrm{~kg}$ kompos jerami padi per $\mathrm{m}^{2},\left(\mathrm{j}_{3}\right)$ 1,5 $\mathrm{kg}$ kompos jerami padi per $\mathrm{m}^{2},\left(\mathrm{j}_{4}\right) 2 \mathrm{~kg}$ kompos jerami padi per $\left.\mathrm{m}^{2}, \mathrm{j}_{5}\right)$ 2,5 $\mathrm{kg}$ kompos jerami padi per $\mathrm{m}^{2},\left(\mathrm{j}_{6}\right) 3 \mathrm{~kg}$ kompos jerami padi per $\mathrm{m}^{2}$

\section{Alat Penelitian}

Alat-alat yang digunakan meliputi: sabit, cangkul, karung plastik, kamera, meteran pita, timbangan, mesin kompos, seperangkat alat tulis.

\section{Bahan Penelitian}

Bahan-bahan dalam penelitian ini terdiri dari: Jerami padi, Pupuk kandang kotoran ayam, $\mathrm{EM}_{4}$, Benih kailan .

\section{Waktu dan Tempat Penelitian}

Penelitian ini dilaksanakan bulan Maret sampai Mei 2016 di Desa Merbang Kecamatan Belitang Hilir 


\section{Hasil Penelitian}

1. Tinggi Tanaman

Data hasil pengamatan pengaruh HASIL DAN PEMBAHASAN kompos jerami padi terhadap tinggi tanaman disajikan pada Tabel 1 .

Tabel 1. Data rerata tinggi tanaman kailan $(\mathrm{cm})$

\begin{tabular}{|c|c|c|c|c|c|c|}
\hline \multirow{2}{*}{ Perlakuan } & \multicolumn{4}{|c|}{ Ulangan } & \multirow{2}{*}{ Jumlah } & \multirow{2}{*}{ Rerata } \\
\hline & I & II & III & IV & & \\
\hline $\mathrm{J}_{0}$ & 26,33 & 27,00 & 27,67 & 36,67 & 117,67 & 29,42 \\
\hline $\mathrm{J}_{1}$ & 33,00 & 28,33 & 31,33 & 27,33 & 120,00 & 30,00 \\
\hline $\mathbf{J}_{2}$ & 33,33 & 26,67 & 32,00 & 33,67 & 125,67 & 31,42 \\
\hline $\mathrm{J}_{3}$ & 37,67 & 28,67 & 38,67 & 39,33 & 144,33 & 36,08 \\
\hline $\mathrm{J}_{4}$ & 43,67 & 57,67 & 44,00 & 45,00 & 190,33 & 47,58 \\
\hline $\mathrm{J}_{5}$ & 48,00 & 50,00 & 49,33 & 44,67 & 192,00 & 48,00 \\
\hline $\mathrm{J}_{6}$ & 58,33 & 55,33 & 60,33 & 50,33 & 224,33 & 56,08 \\
\hline Total & 280,33 & 273,67 & 283,33 & 277,00 & 1114,33 & 39,80 \\
\hline
\end{tabular}

Sumber: pengamatan lapangan, 2016.

Data hasil pengamatan tersebut menggunakan Analisa Sidik Ragam selanjutnya dianalisa dengan disajikan pada Tabel 2.

Tabel 2. Analisis Sidik Ragam pengaruh kompos jerami padi terhadap tinggi tanaman

\begin{tabular}{lcccccc}
\hline \multirow{2}{*}{ SK } & \multirow{2}{*}{ DB } & JK & KT & F Hit. & \multicolumn{2}{c}{ F Tabel } \\
\cline { 5 - 7 } & & & & & $\mathbf{0 , 0 5}$ & $\mathbf{0 , 0 1}$ \\
\hline Ulangan & 3 & 7,47 & 2,49 & $0,11^{\text {tn }}$ & 3,16 & 5,09 \\
Perlakuan & 6 & 2723,66 & 453,94 & $20,39^{* *}$ & 3,66 & 4,01 \\
Galat & 18 & 400,72 & 22,26 & & & \\
\hline Total & $\mathbf{2 7}$ & $\mathbf{3 1 3 1 , 8 5}$ & & \multicolumn{3}{c}{$\mathbf{k k = 1 1 , 8 6 \%}$} \\
\hline
\end{tabular}

Sumber : Pengamatan lapangan, 2016.

Keterangan $:$ tn $=$ tidak berpengaruh nyata pada taraf 0,05

$* *$ = pengaruh sangat nyata pada taraf 0,01 
Hasil analisis ragam pada Tabel 2 yang diamati maka selanjutnya tersebut menunjukan bahwa adanya dilakukan Uji Beda Nyata Jujur yang pengaruh perlakuan terhadap parameter disajikan pada Tabel 3.

Tabel 3. Uji BNJ kompos jerami padi terhadap tinggi tanaman $(\mathrm{cm})$

\begin{tabular}{|c|c|c|c|c|c|c|c|}
\hline Perlakuan & Rerata & \multicolumn{6}{|c|}{ Beda } \\
\hline $\mathrm{J}_{0}$ & $29,42 \mathrm{a}$ & - & & & & & \\
\hline $\mathbf{J}_{1}$ & $30,00 \mathrm{ab}$ & $0,58^{\mathrm{tn}}$ & - & & & & \\
\hline $\mathrm{J}_{2}$ & $31,42 \mathrm{ab}$ & $2,00^{\mathrm{tn}}$ & $1,42^{\mathrm{tn}}$ & - & & & \\
\hline $\mathrm{J}_{3}$ & $36,08 \mathrm{~b}$ & $6,67^{*}$ & $6,08^{*}$ & $4,67^{\mathrm{tn}}$ & - & & \\
\hline $\mathrm{J}_{4}$ & $47,58 \mathrm{c}$ & $18,17^{* *}$ & $17,58^{* *}$ & $16,17^{* *}$ & $11,50^{* *}$ & - & \\
\hline $\mathrm{J}_{5}$ & $48,00 \mathrm{c}$ & $18,58^{* *}$ & $18,00^{* *}$ & $16,58^{* *}$ & $11,92^{* *}$ & $0,42^{\text {tn }}$ & - \\
\hline $\mathrm{J}_{6}$ & $56,08 \mathrm{~d}$ & $26,67^{* *}$ & $26,08^{* *}$ & $24,67^{* *}$ & $20,00^{* *}$ & $8,50^{* *}$ & $\begin{array}{c}8,08 \\
* *\end{array}$ \\
\hline \multicolumn{8}{|c|}{ sy $=1,18$} \\
\hline \multicolumn{2}{|c|}{ Q $0,05=4,67$} & \multicolumn{6}{|c|}{ BNJ $0.05=5,51$} \\
\hline \multicolumn{2}{|c|}{$Q 0,01=5,79$} & & & & & \multicolumn{2}{|c|}{ BNJ $0.01=6,83$} \\
\hline
\end{tabular}

Keterangan $:$ tn $=$ tidak beda nyata pada taraf 0,05

** = beda sangat nyata pada taraf 0,01

Angka yang tandai huruf sama menunjukkan tidak beda nyata pada nilai BNJ 0,05

Hasil Uji BNJ pada Tabel 3 menunjukkan bahwa perlakukan kompos jerami padi menghasilkan tinggi tanaman kailan yang lebih tinggi dibandingkan dengan tanpa pemberian kompos jerami padi.

\section{Diameter Batang}

Hasil pengamatan pengaruh kompos jerami padi terhadap diameter batang dapat dilihat Tabel 4. Data hasil Tabel 4. Data rerata diameter batang tanaman (mm) pengamatan tersebut selanjutnya dianalisa dengan menggunakan Analisa Sidik Ragam yang disajikan pada Tabel 5.

Hasil analisis ragam pada Tabel 5 tersebut menunjukan bahwa adanya pengaruh perlakuan terhadap parameter yang diamati maka selanjutnya dilakukan Uji Beda Nyata Jujur yang disajikan pada Tabel 6. 


\begin{tabular}{|c|c|c|c|c|c|c|}
\hline \multirow{2}{*}{ Perlakuan } & \multicolumn{4}{|c|}{ Ulangan } & \multirow{2}{*}{ Jumlah } & \multirow{2}{*}{ Rerata } \\
\hline & I & II & III & IV & & \\
\hline $\mathbf{J}_{0}$ & 3,67 & 4,00 & 4,33 & 4,33 & 16,33 & 4,08 \\
\hline $\mathrm{J}_{1}$ & 6,00 & 6,33 & 6,33 & 5,67 & 24,33 & 6,08 \\
\hline $\mathbf{J}_{2}$ & 6,67 & 7,00 & 7,33 & 7,00 & 28,00 & 7,00 \\
\hline $\mathrm{J}_{3}$ & 9,00 & 9,33 & 9,67 & 9,33 & 37,33 & 9,33 \\
\hline $\mathrm{J}_{4}$ & 11,67 & 11,67 & 12,00 & 11,33 & 46,67 & 11,67 \\
\hline $\mathrm{J}_{5}$ & 14,33 & 12,33 & 12,67 & 13,33 & 52,67 & 13,17 \\
\hline $\mathrm{J}_{6}$ & 17,00 & 16,67 & 17,33 & 18,33 & 69,33 & 17,33 \\
\hline Total & 68,33 & 67,33 & 69,67 & 69,33 & 274,67 & 9,81 \\
\hline
\end{tabular}

Sumber: pengamatan lapangan, 2016.

Tabel 5. Analisis Sidik Ragam pengaruh kompos jerami padi terhadap diameter batang

\begin{tabular}{lcccccc}
\hline \multirow{1}{*}{ SK } & DB & JK & \multirow{2}{*}{ KT } & F Hit. & \multicolumn{2}{c}{ F Tabel } \\
\cline { 5 - 7 } & & & & & $\mathbf{0 , 0 5}$ & $\mathbf{0 , 0 1}$ \\
\hline Ulangan & 3 & 0,48 & 0,16 & $0,61^{\text {tn }}$ & 3,16 & 5,09 \\
Perlakuan & 6 & 504,48 & 84,08 & $322,66^{* *}$ & 3,66 & 4,01 \\
Galat & 18 & 4,69 & 0,26 & & & \\
\hline Total & $\mathbf{2 7}$ & $\mathbf{5 0 9 , 6 5}$ & & $\mathbf{k k}=\mathbf{5 , 2 0 \%}$ & \\
\hline
\end{tabular}

Sumber : pengamatan lapangan, 2016.

Keterangan $:$ tn $=$ tidak berpengaruh nyata pada taraf 0,05

$* *$ = pengaruh sangat nyata pada taraf 0,01

Tabel 6. Uji BNJ kompos jerami padi terhadap diameter batang (mm) 

Kailan (Brassica alboglabra, L.) Pada Tanah Podsolik Merah Kuning

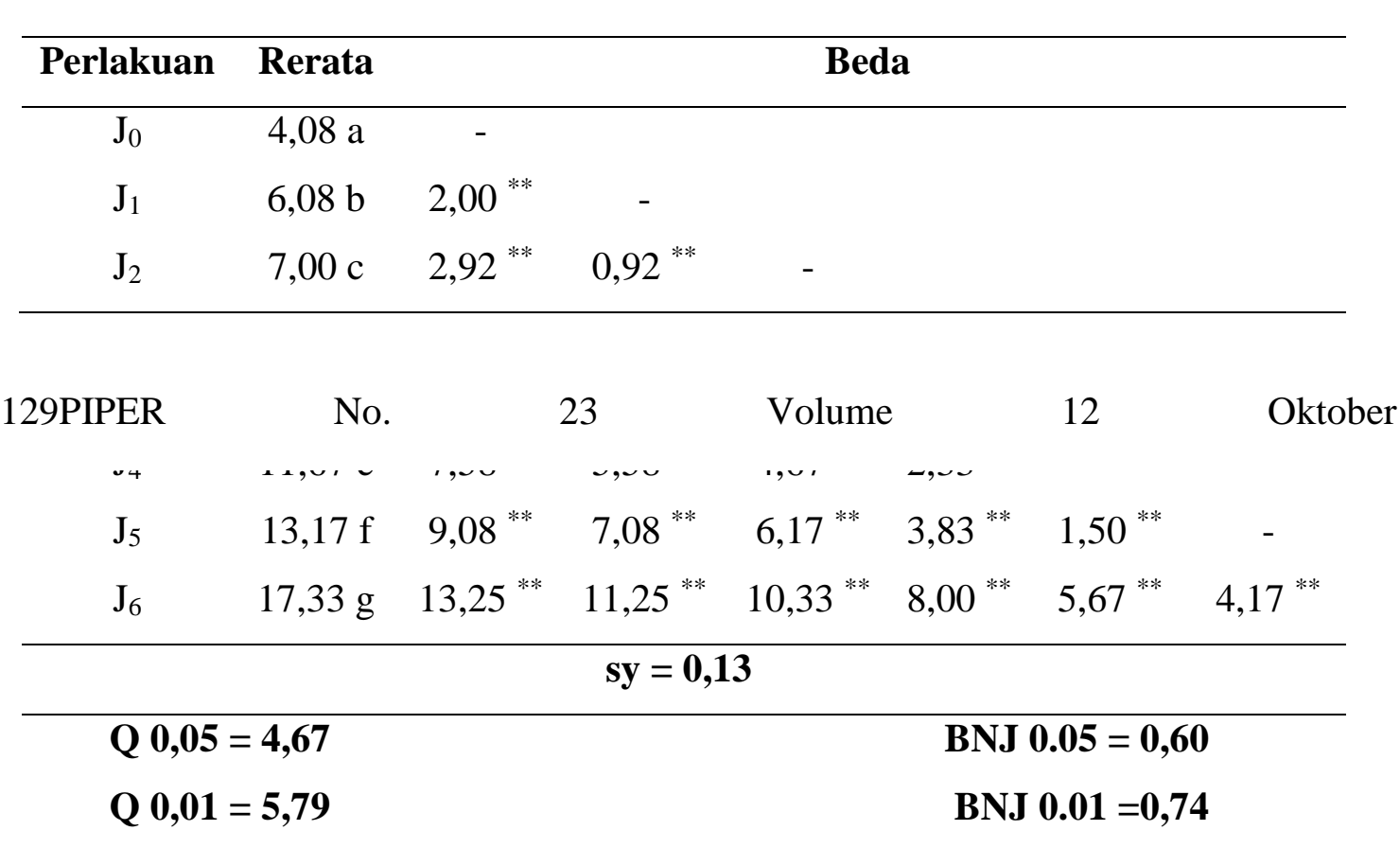

Keterangan $:$ tn $=$ tidak beda nyata pada taraf 0,05

$* *$ = beda sangat nyata pada taraf 0,01

Hasil uji BNJ menunjukkan bahwa semakin tinggi dosis kompos jerami padi diberikan diikuti dengan besarnya diameter batang tanaman kailan
3. Berat Segar Tanaman

Data hasil pengamatan pengaruh kompos jerami padi terhadap berat segar tanaman dapat dilihat dalam dalam Tabel 7.

Tabel 7. Data rerata berat segar tanaman (g)

\begin{tabular}{|c|c|c|c|c|c|c|}
\hline \multirow{2}{*}{ Perlakuan } & \multicolumn{4}{|c|}{ Ulangan } & \multirow{2}{*}{ Jumlah } & \multirow{2}{*}{ Rerata } \\
\hline & I & II & III & IV & & \\
\hline $\mathrm{J}_{0}$ & 13,33 & 20,00 & 18,33 & 15,00 & 66,67 & 16,67 \\
\hline $\mathrm{J}_{1}$ & 33,33 & 40,00 & 36,67 & 33,33 & 143,33 & 35,83 \\
\hline $\mathbf{J}_{2}$ & 40,00 & 66,67 & 45,00 & 40,00 & 191,67 & 47,92 \\
\hline $\mathbf{J}_{3}$ & 70,00 & 83,33 & 80,00 & 66,67 & 300,00 & 75,00 \\
\hline $\mathrm{J}_{4}$ & 143,33 & 150,00 & 143,33 & 133,33 & 570,00 & 142,50 \\
\hline $\mathrm{J}_{5}$ & 203,33 & 193,33 & 200,00 & 204,33 & 801,00 & 200,25 \\
\hline $\mathrm{J}_{6}$ & 266,67 & 260,00 & 265,00 & 270,00 & 1061,67 & 265,42 \\
\hline Total & 770,00 & 813,33 & 788,33 & 762,67 & 3134,33 & 111,94 \\
\hline
\end{tabular}


Sumber: pengamatan lapangan, 2016.

Data hasil pengamatan tersebut selanjutnya dianalisa dengan menggunakan Analisa Sidik Ragam yang disajikan pada Tabel 8 .

Tabel 8. Analisis Sidik ragam pengaruh kompos jerami padi terhadap berat segar

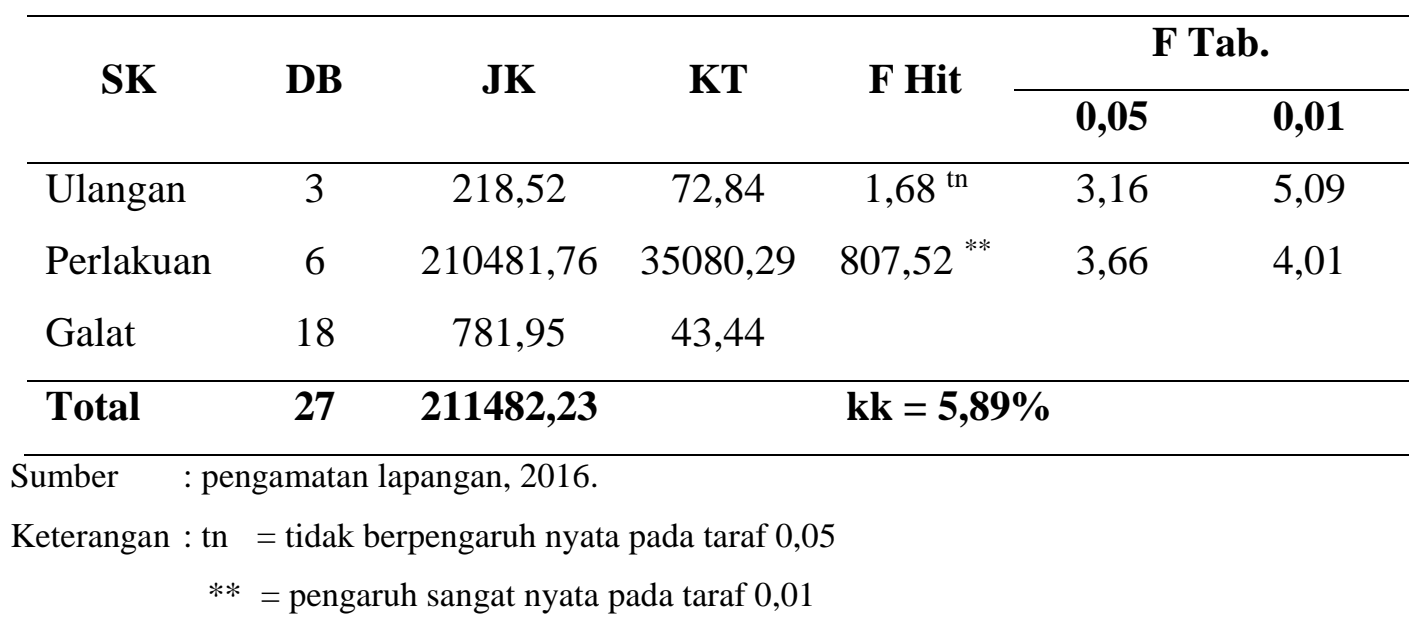

Hasil analisis ragam pada Tabel 8 tersebut menunjukan bahwa adanya pengaruh perlakuan terhadap parameter yang diamati maka selanjutnya dilakukan Uji Beda Nyata Jujur yang disajikan pada Tabel 9.

Tabel 9. Uji BNJ kompos jerami padi terhadap berat segar tanaman (g)

\begin{tabular}{cccccccc}
\hline Perlakuan & Rerata & \multicolumn{5}{c}{ Beda } \\
\hline $\mathrm{J}_{0}$ & $16,67 \mathrm{a}$ & - & & & & \\
$\mathrm{J}_{1}$ & $35,83 \mathrm{~b}$ & $19,17^{* *}$ & - & & & \\
$\mathrm{J}_{2}$ & $47,92 \mathrm{c}$ & $31,25^{* *}$ & $12,08^{* *}$ & - & & \\
$\mathrm{J}_{3}$ & $75,00 \mathrm{~d}$ & $58,33^{* *}$ & $39,17^{* *}$ & $27,08^{* *}$ & - & & \\
$\mathrm{J}_{4}$ & $142,50 \mathrm{e}$ & $125,83^{* *}$ & $106,67^{* *}$ & $94,58^{* *}$ & $67,50^{* *}$ & - & - \\
$\mathrm{J}_{5}$ & $200,25 \mathrm{f}$ & $183,58^{* *}$ & $164,42^{* *}$ & $152,33^{* *}$ & $125,25^{* *}$ & $57,75^{* *}$ & - \\
$\mathrm{J}_{6}$ & $265,42 \mathrm{~g}$ & $248,75^{* *}$ & $229,58^{* *}$ & $217,50^{* *}$ & $190,42^{* *}$ & $122,92^{* * *}$ & 65,17 \\
& & & & & & & \\
\hline \\
\hline
\end{tabular}

Keterangan $:$ tn $=$ tidak beda nyata pada taraf 0,05 
Hasil uji BNJ menunjukkan bahwa semakin tinggi dosis kompos jerami padi diberikan diikuti dengan berat segar tanaman artinya bahwa

131PIPER

No.

23

\section{Pembahasan}

Hasil penelitian menunjukkan bahwa semakin tinggi dosis kompos jerami diberikan pada tanah PMK menyebabkan pertumbuhan dan hasil tanaman yang semakin tinggi, hasil ini terlihat pada pengamatan tinggi tanaman, diameter batang dan berat segar tanaman. Meningkatnya tinggi tanaman, diameter batang dan berat segar disebabkan oleh membaiknya kondisi tanah sehingga unsur-unsur hara yang diperlukan oleh tanaman kailan terserap dengan baik. Gusmailina dan Komarayati (2003:21-30), menyatakan bahwa pupuk organik seperti kompos jerami padi dapat memperbaiki struktur dan tekstur tanah. Penggunaan kompos jerami padi mengurangi pemadatan tanah karena semakin banyak pori-pori, dan menyebabkan akar tanaman semakin tumbuh lebih baik sehingga tingkat pengambilan hara semakin tinggi sesuai kebutuhan tanaman.

Syukur dan Indah (2006:124131), penambahan bahan organik

Volume 12

Oktober

tanah. Semakin banyak bahan organik yang ditambahkan kedalam tanah semakin banyak pula $\mathrm{C}$ organik yang dilepaskan kedalam tanah. Akibat dari pemberian kompos jerami padi pada tanah PMK menyebabkan kondisi tanah menjadi lebih baik terutama ketersediaan hara seperti N, P, K, dan unsur-unsur hara mikro bagi tanaman kailan.

Menurut Anonim (2013:1) bahwa kandungan hara yang terdapat dalam kompos jerami padi adalah $\mathrm{C} / \mathrm{N}$ rasio $=18,88 \%, \mathrm{C}=35,11 \%, \mathrm{~N}=1,86 \%$, $\mathrm{P}_{2} \mathrm{O}_{5}=0,21 \%, \mathrm{~K}_{2} \mathrm{O}=5,35 \%, \mathrm{Cmol} / \mathrm{kg}$, $\mathrm{Ca}=0.42 \mathrm{Cmol} / \mathrm{kg}, \mathrm{Mg}=0.25 \mathrm{Cmol} / \mathrm{kg}$, dari hasil analisis tersebut pemberian kompos jerami masih memungkinkan untuk diberikan dalam jumlah dosis yang lebih tinggi lagi untuk dapat meningkatkan hasil tanaman. Tersedianya unsur-unsur hara makro dan mikro akibat pemberian kompos jerami padi menyebabkan pembentukan sel-sel yang berperan dalam pemanjangan 
batang tanaman, penambahan ukuran batang, dan perbanyakan sel-sel dalam tubuh tanaman menjadi lebih baik. Akibatnya berpengaruh pada tinggi tanaman, diameter batang, dan berat segar tanaman yang lebih baik daripada tanaman yang tidak diberi kompos jerami padi.

Kandungan unsur Nitrogen yang terdapat dalam kompos jerami padi sangat berperan aktif merangsang pertumbuhan bagian sel tanaman. Setyamidjaja (1986:16) menjelaskan bahwa Nitrogen berperan merangsang pertumbuhan vegetatif seperti menambah tinggi tanaman, merangsang tumbuhnya anakan, menyusun klorofil/butir-butir hijau daun untuk fotosintesis lebih tinggi, menyusun lemak dan protein.

Selanjutnya menurut Harjadi (1991:103), pembelahan sel pada fase vegetatif terjadi pada pembuatan sel-sel baru terutama pada jaringan-jaringan meristematik titik tumbuh batang dan akar. Sel-sel baru ini memerlukan karbohidrat dalam jumlah besar, karena dinding-dindingnya terbuat dari selulosa dan protoplasma kebanyakan terbuat dari gula, sehingga bila faktor-faktor lain tersedia dalam keadaan seimbang maka laju pembelahan sel tergantung pada persediaan karbohidrat.

Unsur Nitrogen membentuk asam amino sebagai kerangka protein sehingga proses pembelahan, pembesaran serta perpanjangan sel dapat berjalan lancar. Lingga (1990:9) menjelaskan bahwa Nitrogen berperan untuk merangsang pertumbuhan secara keseluruhan. Lebih lanjut Dwidjoseputro (1992:15) menjelaskan bahwa Nitrogen berperan untuk pembentukan butir hijau daun yang merupakan faktor keharusan untuk berlangsungnya fotosintesis. Menurut Harjadi (1991:96), hasil-hasil fotosintesis sebagian digunakan untuk menyusun jaringan tanaman dan sebagian digunakan untuk kegiatan metabolisme tanaman.

\section{KESIMPULAN DAN SARAN}

\section{Kesimpulan}

Berdasarkan hasil pengamatan dapat ditarik kesimpulan sebagai berikut:

1. Kompos jerami padi berpengaruh terhadap pertumbuhan dan hasil tanaman kailan pada tanah PMK.

2. Dosis kompos jerami padi $3 \mathrm{~kg}$ per $\mathrm{m}^{2}$ atau 30 ton per hektar memberikan pengaruh terbaik terhadap tinggi tanaman dengan rata-rata $56,08 \mathrm{~cm}$, diameter batang rata-rata $17,33 \mathrm{~mm}$, 
dan berat segar rata-rata 265,42 gram

per tanaman.

\section{Saran}

Melalui hasil penelitian ini disarankan untuk:

1. Memberikan kompos jerami padi pada tanah PMK, terutama dalam membudidayakan tanaman kailan.

2. Dalam mengembangkan tanaman kailan pada tanah PMK pemberian kompos jerami padi dengan dosis 30 ton per hektar sangat disarankan. 


\section{DAFTAR PUSTAKA}

Badan Pusat Statistik Kabupaten Sekadau. 2015. Kabupaten Sekadau Dalam Angka. Sekadau: BPS Sekadau.

Barus, J. 2011. Uji Efektivitas Kompos Jerami dan Pupuk NPK Terhadap Hasil Padi. Jurnal Agrivigor. 10(3): 247-252, Mei - Agustus 2011; ISSN 1412-2286. Balai Pengkajian Teknologi Pertanian Lampung.

Buckman, H.O and N.C. Brady, 1982. Ilmu Tanah. Diterjemahkan oleh Soegiman, Jakarta: Bharata Karya Aksara.

Darmawijaya, M.I. 1990. Klasifikasi Tanah. Dasar Teori Bagi Peneliti Tanah dan Pelaksana Pertanian di Indonesia. Yogyakarta: UGM Press.

Foth, HD., 1994. Dasar-Dasar Ilmu Tanah. Diterjemahkan Adi Sumartono, Jakarta: Airlangga.

Gasperz. VE. 1994. Rancangan Percobaan. Bandung: Armico.

Gusmailina, G. P. dan S. Komarayati. 2003. Pengembangan Penggunaan Arang untuk Rehabilitasi Lahan. Bulletin Penelitian dan Pengembangan Kehutanan, Vol. 4 (1), halaman: 21-30.

Hakim, N. Nyakpa, M.Y. Lubis, A.M., Nugroho, S.G. Saul, M.R., Diha, M.A., Hong, G.B., Balley, H.H. 1996. Dasar-Dasar Ilmu Tanah. Bandar Lampung: Universitas Lampung.

Hardiatmi. 2006. Karakteristik Kompos Dari Bahan Tanaman. Repository IPB.

Hardjowigeno. 2003. Ilmu Tanah. Jakarta: Akademika Pressindo.

Hartati dan Adiningsih. 1987. Karakteristik Tanah Ultisol. Repro Ilmu Tanah UGM.

Junaedi. 2008. Pemupukan Fosfor dan Kompos Jerami Pada Tanah Ultisol. Repository Universitas Diponegoro.

Lingga, P., dan Marsono. 2009. Petunjuk Penggunaan Pupuk. Jakarta: Penebar Swadaya.

Nyakpa, M.Y., Lubis, A.M, Pulung, M.A., Amrah, A.G., Munawar.A., Hong.G.B., Hakim, N., 1988. Kesuburan Tanah dan Pemupukan. Lampung: Universitas Lampung.

Purnomo. 2004. Pengujian Kandungan Unsur Hara Dalam Kompos Jerami Padi dan Jerami Jagung. unilak.ac.id.

Rukmana, R. 2007. Bercocok Tanam Sawi dan Kailan. Yogyakarta: Kanisius.

Syarif, ES. 1986. Ilmu Tanah Pertanian. Jakarta: Pustaka Buana.

Syukur, A. dan N. M. Indah. 2006. Kajian Pengaruh Pemberian Macam Pupuk Organik Terhadap Pertumbuhan dan Hasil Tanaman Jahe di Inceptisol, Karanganyar. Jurnal Ilmu Tanah dan Lingkungan, Vol. 6 (2), halaman:124-131. 